\title{
REDISTRIBUTIVE EFFECT OF TAXES AND TRANSFERS: EVIDENCE FROM CHINA
}

\author{
Liu Baihui \\ Chinese Academy of Social Science, Beijing, China
}

\begin{abstract}
China's sustained high-speed several-decade-long economic growth has raised the level of per capita income, but also brought about a serious income gap. Taxes and public transfers are main policy governmental tools in the process of redistribution. This paper leads a comprehensive analysis of the impacts of taxes and transfers on income redistribution using decomposition method and is based on China's Urban Household Survey Data (2002-2009) derived from the National Bureau of Statistics of China. The empirical results reveal that government's net transfer reduces urban household's increasing market income inequality, and the improvement effect increases with time. Taking a closer look, it shows that both tax and transfer play positive adjusting roles. Transfer's contribution is relatively larger, reflected mainly in the improvement of horizontal equality, while tax's effect is mainly reflected in vertical equality. On the whole, the combined redistribution effect of personal income tax and social insurance expenses from residents to government is positive, and can play a role in regulating the income redistribution. Endowment insurance, social relief and unemployment insurance reduce inequality in the transfers of government to residents, even though the last two items' effects are very weak. In contrast, provident fund expands income gap. The conclusions reached in this paper will refer to the refinement of income distribution reform, promotion of tax reform, and improvement of the social security system
\end{abstract}

KEYWORDS tax revenue and expenditure; income redistribution; vertical equality; horizontal equality

\section{HIGHLIGHTS}

1. The comparative analysis of tax and transfer impact on income redistribution has been done based on the research of urban households in China in 2002-2009

2. Rising positive impact of net transfers from the budget on the reduction of income inequality among urban population is demonstrated

3. The impact of transfers on horizontal inequality reduction, and the impact of taxes on vertical inequality reduction is established

4 . The need to continue the tax reform and improve the social security system in order to reduce the inequality in the income of the population is demonstrated

\section{ПЕРЕРАСПРЕАЕАИТЕАЬНЫЕ ЭФФЕКТЫ НАЛОГОВ И ТРАНСФЕРТОВ: ОПЫТ КИТАЯ}

\author{
Лиу Байхиу \\ Китайская академия соииальных наук, г. Пекин, Китай
}

\begin{abstract}
АННОТАЦИЯ Устойчивый и быстрый экономический рост Китая в течение последних десятилетий привел не только к повышению уровня доходов на душу населения, но также и к серьезному разрыву в доходах отдельных категорий граждан. Основными инструментами государственной политики перераспределения доходов являются налоги и трансферты. В статье анализируется их влияние на перераспределение доходов. Исследование проводилось с использованием метода декомпозиции на основе данных обследования городских домашних хозяйств Китая в 2002-2009 гг., представленных Национальным бюро статистики Китая. Эмпирические результаты исследования указывают на то, что чистые трансферты из бюджета сокращают неравенство доходов среди городского населения, и этот положительный эффект со вре-
\end{abstract}


менем возрастает. Подробное изучение данного вопроса показывает, что и налоги, и трансферты играют позитивную роль в корректировке неравномерного распределения доходов. Трансферты влияют в основном на сокращение горизонтального неравенства и вносят более значительный вклад в корректировку ситуации, чем налоги, которые главным образом способствуют сокращению вертикального неравенства. В целом, совместный перераспределительный эффект персонального подоходного налога и взносов на социальное страхование носит благоприятный характер и может использоваться для перераспределения доходов. Трансферты резидентам из государственного бюджета, страхование вкладов, социальная помощь и страхование от безработицы также уменьшают неравенство, однако эффект последних двух мер очень слабый. Резервный фонд, напротив, увеличивает разрыв в доходах. Выводы, сделанные по результатам исследования могут быть использованы при дальнейшем реформировании распределения доходов и продвижении налоговой реформы, а также в совершенствовании системы социального обеспечения

КЛЮЧЕВЫЕ СЛОВА Налоговые поступления и расходы; перераспределение доходов; вертикальное равенство; горизонтальное равенство

\section{ОСНОВНЫЕ ПОЛОЖЕНИЯ}

1. Проведен сравнительный анализ влияния налогов и трансфертов на перераспределение доходов на основе данных обследования городских домашних хозяйств в Китае за 2002-2009 гг.

2. Выявлено возрастающее положительное влияние чистых трансфертов из бюджета на сокращение неравенство доходов среди городского населения

3. Установлено влияние трансфертов на сокращение горизонтального неравенства, а налогов на сокращение вертикального неравенства

4. Показана необходимость продолжения налоговой реформы и совершенствования системы социального обеспечения с целью сокращения разрыва в доходах населения

\section{Introduction}

While raising per capita income levels, China's sustained high-speed economic growth for several decades has also brought a serious income gap. Especially after 2008, the social contradictions caused by income distribution have amplified further under the influence of the financial crisis, which occurred in many areas of economy and society, and has become one of the key problems in sustainable development. The whole society has reached a critical stage of breaking up income gap and unfair income distribution.

In fact, the Chinese government has made great endeavor in exploring the establishment of policies promoting social equity in the past 10 years. At the same time, however, it should also be noticed that the disputes over distribution inequity are getting stronger. While continuing to promote the perfection of redistribution system, two questions have to be answered. The first is how to evaluate the redistribution role of current Chinese government's revenue and expenditure system, and the second is how big is a role that each distribution instrument has played. The answers can not only verify the role of Chinese government in adjusting social income distribution and making up the defects of the market, but can also provide the basis for mutual matching and comprehensive development of relevant policies in practice.

Compared with similar works focusing on China, this paper has the following contributions. First, it tries to break through the barriers of considering redistribution of policies separately, and measure the effect of a package of policies together. Second, in order to arrive at a more comprehensive and in-depth conclusion, it compares the effects of each of the policies taking interactions among different policies into account.

\section{Literature Review}

Studies on redistribution effect of government revenue and expenditure starts 
from progressivity of income tax, and can be retrieved to R. A. Musgrave and T. Thin [1], where income elasticity of tax burden or taxable income are used as the index of progressivity measure. In the late 1970s, a group of scholars constructed a single numerical index based on the Lorenz curve, which was used to measure the overall progressivity of a tax system [2; 3]. In the 1980s, schorlars advocated a more detailed analysis of the data so that policymakers could be well aware of the situations faced by various income groups in the distribution [4]. Since coordinate values on the Lorenz curve are based on samples, Lorenz advantage test is introduced to determine the significance of differences between different curves [5].

However, the progressive indicators mentioned above are closely related to vertical equity. Since Feldstein introduced the concept of horizontal equity in 1976, scholars have tried to break up the redistribution effect by decomposeing horizontal equity from vertical equity and this exploration goes through the three phases. The first is APK decomposition, which mixes horizontal and vertical equity by focusing only on relative sorting changes without limiting the income groups [6-8]. The second phase is AJL decomposition, which decomposes the redistribution effect into vertical equity, horizontal equity, and reranking effect by separating horizontal effect from vertical effect $[9 ; 10]$. The third phase is the UL method, by which the AJL decomposition method is amended to relax the hypothesis of inter-group and intra-group reordering problem [11]. The redistribution effect can then be completely decomposed into vertical effect, horizontal effect and reordering effect. Based on the evolution of the above theoretical model, many issues on public revenue and expenditure have been analyzed [12-17].

There is a wide range of polices used to regulate income distribution, which are often associated with each other. In the comprehensive assessment of the set of fiscal revenue and expenditure policies impact on income distribution, an additional interaction between the policies should be taken into account. In the early days it is typical to add different order of policies, but the subjective order selection will affect the result. One solution is judging policy contribution by breaking down the net budget effect, but it must be based on the absence of a reordering effect [18]. In order to correct the deviations of estimated results caused by reordering, Duclos computes the results of each possible sort using the sequential method, but he still can not give the definite answer [19]. Urban uses a "micro-approach" to solve this problem: people are grouped by income, and after the examination of the difference in tax burden and transfer payment, an integration between groups is achieved [20].

In the existing works about China, redistribution effects of important government revenue and expenditure aspects are examined, but the representative empirical articles only decompose the differences of Gini coefficients before and after taxation based on "effective progression". In terms of government expenditure, analyses mainly focus on medical and health financing, urban subsistence allowances, and so on. Since the problems discussed are singular, the methods used are MT index decomposition, Theil index decomposition, etc., and they can't achieve a thorough decomposition of inequality. In general, there are no results in literature on the overall inspection of the redistribution effect of China's fiscal revenue and expenditure policies.

\section{Research Method}

Decomposition of Redistribution Effect of Tax and Transfer. The relationship between the progressive index $K$ and the redistribution effect $V$ can be expressed as $^{1}$,

$$
\begin{aligned}
& V_{T}=\frac{t}{1-t} K_{T}, \\
& V_{E}=\frac{e}{1+e} K_{E} .
\end{aligned}
$$

${ }^{1}$ Due to the limited space, the specific proof of the process is omitted here, which interested readers can obtain from the author. 
In which

$$
t=\frac{\mu_{T}}{\mu_{\mathrm{X}}} \text { and } e=\frac{\mu_{E}}{\mu_{\mathrm{X}}}
$$

are the average transfer rate of household transfer expenditure and income respectively.

Same as the derivation of (1), the net income redistribution effect can be written as,

$$
V_{N}=\frac{t}{1+e-t} K_{T}+\frac{e}{1+e-t} K_{E} .
$$

In which

$$
\frac{t}{1+e-t} \text { and } \frac{e}{1+e-t}
$$

represent the contribution of taxation and transfer payments to redistribution respectively. Through (2), we can measure the different degrees of importance of taxation and transfer in income redistribution.

Merging (1) and (2), the following equation can be get,

$$
V_{N}=\frac{1-t}{1+e-t} V_{T}+\frac{1+e}{1+e-t} V_{E}
$$

Therefore, $V_{N}$ can be calculated by $V_{T}$ and $V_{E}$, but not their weighted average.

The Redistributive Effect of Single Policy. In a separate measure of the role of a policy, the redistribution effect consists of vertical redistribution and reordering effects. For each tax and transfer policy, it can be expressed as,

$$
R E=\frac{g}{1-g} P_{K}-\left(G_{N}-C_{N}\right)=V^{K}-R^{K} .
$$

J. R. Aronson, P. Johnson and P. J. Lambert (1994) improve equation (4), and decompose the redistribution effect into horizontal fairness, vertical fairness and sorting effect [10].

$$
R E=V^{A J L}-H^{A J L}-R^{A J L} .
$$

This method needs to break down the data into several equal income groups, and therefore does not take into account the reordering effect within group $R^{W G}$ and between groups $R^{B G}$. In view of this, I. Urban, P. J. Lambert (2008) [11], I. Urban (2010) [20] proposed UL decomposition method on the basis of improving the decomposition method in (5).

$$
R E=V^{U L}-H^{U L}-R^{K} .
$$

The meaning of $R^{K}$ in (6) is the same as in (4). Besides,

$$
\begin{gathered}
V^{U L}=V^{A J L}+R^{B G}, \\
H^{U L}=V^{A J L}-R^{W G,} \\
R^{K}=R^{A J L}+R^{B G}+R^{W G} .
\end{gathered}
$$

\section{Data Description and Processing}

Data description. The data used in this paper is derived from the National Bureau of Urban Household Survey (UHS) (2002-2009) of the National Bureau of Statistics of China. This survey covers all provinces in China, using stratified sampling to obtain samples, and has the longest investigation period and largest sample compared to other domestic data. All samples are rotated by $1 / 3$ each year and have a detailed record of the household membership composition and the amount of income and expenditure. Table 1 lists the basic statistics of main variables ${ }^{2}$.

Data Processing. After the series of indicators comparison and data integration, the correspondence between revenue and expenditure indicators and information in the database are established. The Adult Equivalent Scale factor is also used in this paper to adjust the size of family. If the number of adult and child in a family are $N_{A}$ and $N_{C}$ respectively, this family includes $Z=\left(N_{A}+\phi N_{C}\right)^{\theta}$ equivalent families, in which $\phi$ is consumer demand of child relative to adult, and $\theta$ is family economies of scale. The formula assumes that adults and children in the family are the only non-income factors that affect demand. This paper uses the method of J. R. Aronson, P. Johnson and P. J. Lambert [9], A. Wagstaff et al. [14] to set the relationship between parameters as

$$
\phi=\theta=\frac{1}{2} .
$$

${ }^{2}$ Due to space limitation, detailed data on tax and transfer are omitted. Readers who are interested in this can obtain from the author. 


\section{Empirical Results}

Redistribution Effects of Government Net Income and Expenditure and it's Decomposition. The measurement of the redistribution effect of fiscal net income and expenditure can comprehensively reflect the impact of current government revenue and expenditure policies on income distribution, and can facilitate the formation of the overall evaluation. On the basis of total effect calculating, this paper decomposes it into two aspects: the influence of taxation and the effect of transfer payment. The main results are shown in Table 2. The following conclusions can be drawn from the empirical results.

First, the Gini coefficient of urban residents' market income rose from 0.3888 in 2002 to 0.4207 in 2009 , which showed an

Statistical description of key indicators

Table 1

\begin{tabular}{|r|r|r|r|r|r|r|r|r|r|}
\hline Year & Sample & \multicolumn{2}{|c|}{ Market incme } & \multicolumn{2}{c|}{ Tax } & \multicolumn{2}{c|}{ Transfer } & \multicolumn{2}{c|}{ Net income } \\
\cline { 3 - 10 } & mean & variance & mean & variance & mean & variance & mean & variance \\
\hline 2002 & 12813 & 15053.5 & 8662.8 & 856.7 & 1244.9 & 3124.1 & 5361.3 & 14297.1 & 8093.6 \\
\hline 2003 & 14288 & 15745.9 & 9864.2 & 1037.7 & 1556.1 & 3102.7 & 5426.1 & 14827.8 & 9077.9 \\
\hline 2004 & 15505 & 18448.1 & 11612.4 & 1337.0 & 1964.7 & 3724.7 & 6497.1 & 17242.8 & 10665.6 \\
\hline 2005 & 16648 & 20384.6 & 12834.6 & 1550.7 & 2282.5 & 4330.5 & 7265.6 & 18985.0 & 11804.5 \\
\hline 2006 & 16831 & 22904.7 & 14214.2 & 1847.4 & 2670.3 & 4765.7 & 7824.2 & 21244.8 & 12991.1 \\
\hline 2007 & 16856 & 25765.0 & 15363.8 & 2119.0 & 2964.8 & 5461.8 & 9071.0 & 23732.6 & 13998.3 \\
\hline 2008 & 16856 & 27315.6 & 17238.1 & 2190.0 & 3243.7 & 5762.3 & 9638.7 & 25336.6 & 15748.1 \\
\hline 2009 & 16856 & 31351.0 & 18804.8 & 2974.8 & 3899.6 & 6865.8 & 11349.2 & 28631.3 & 17024.1 \\
\hline
\end{tabular}

Table 2

Redistribution Effects of Government Net Income and Expenditure and it's Decomposition

\begin{tabular}{|c|c|c|c|c|c|c|c|c|}
\hline Indicators & 2002 & 2003 & 2004 & 2005 & 2006 & 2007 & 2008 & 2009 \\
\hline ome $(N=T-B)$ & & & & & & & & \\
\hline $\begin{array}{l}\text { Gini Coefficient before } \\
\text { Transfer }\end{array}$ & 0.3888 & 0.4021 & 0.4028 & 0.4136 & 0.4116 & 0.4072 & 0.4255 & 0.4207 \\
\hline $\begin{array}{l}\text { Gini Coefficient after } \\
\text { Transfer }\end{array}$ & 0.3041 & 0.3224 & 0.3192 & 0.3207 & 0.3200 & 0.3151 & 0.3235 & 0.3146 \\
\hline Redistribution Effect & 0.0846 & 0.0797 & 0.0836 & 0.0930 & 0.0916 & 0.0921 & 0.1020 & 0.1061 \\
\hline$\%$ & 21.77 & 19.82 & 20.75 & 22.48 & 22.25 & 22.62 & 23.98 & 25.22 \\
\hline Average Tax Rate & -0.1516 & -0.1298 & -0.1194 & -0.1339 & -0.1182 & -0.1160 & -0.1303 & -0.1319 \\
\hline $\begin{array}{l}\text { Contribution of Govern- } \\
\text { ment Net Expenditure } V^{N}\end{array}$ & 0.1542 & 0.1423 & 0.1493 & 0.1623 & 0.1555 & 0.1619 & 0.1761 & 0.1896 \\
\hline Contribution of Tax & 0.0040 & 0.0048 & 0.0059 & 0.0069 & 0.0074 & 0.0061 & 0.0055 & 0.0043 \\
\hline$\%$ & 2.62 & 3.35 & 3.98 & 4.25 & 4.78 & 3.77 & 3.12 & 2.28 \\
\hline $\begin{array}{l}\text { Contribution of Govern- } \\
\text { ment Subsidy }\end{array}$ & 0.1501 & 0.1375 & 0.1433 & 0.1554 & 0.1481 & 0.1558 & 0.1706 & 0.1853 \\
\hline$\%$ & 97.38 & 96.65 & 96.02 & 95.75 & 95.22 & 96.23 & 96.88 & 97.72 \\
\hline Vertical Ec & 0.1464 & 0.1332 & 0.1379 & 0.1508 & 0.1488 & 0.1548 & 0.1543 & 0.1839 \\
\hline$\%$ & 173.02 & 167.09 & 164.96 & 162.20 & 162.47 & 168.07 & 151.20 & 173.30 \\
\hline Horizontal Equality & -0.0078 & -0.0091 & -0.0114 & -0.0115 & -0.0067 & -0.0070 & -0.0218 & -0.0057 \\
\hline$\%$ & -9.17 & -11.39 & -13.69 & -12.37 & -7.32 & -7.64 & -21.39 & -5.38 \\
\hline Reordering E & 0.0695 & 0.0625 & 0.0657 & 0.0693 & 0.0639 & 0.0697 & 0.0741 & 0.0835 \\
\hline$\%$ & 82.18 & 78.48 & 78.64 & 74.57 & 69.79 & 75.70 & 72.59 & 78.68 \\
\hline $\operatorname{Tax} T$ & & & & & & & & \\
\hline $\begin{array}{l}\text { Gini Coefficient before } \\
\text { Transfer }\end{array}$ & 0.3888 & 0.4021 & 0.4028 & 0.4136 & 0.4116 & 0.4072 & 0.4255 & 0.4207 \\
\hline
\end{tabular}


End of the table 2

\begin{tabular}{|c|c|c|c|c|c|c|c|c|}
\hline Indicators & 2002 & 2003 & 2004 & 2005 & 2006 & 2007 & 2008 & 2009 \\
\hline $\begin{array}{l}\text { Gini Coefficient after } \\
\text { Transfer }\end{array}$ & 0.3856 & 0.3986 & 0.3983 & 0.4081 & 0.4058 & 0.4032 & 0.4222 & 0.4191 \\
\hline Redistribution Effect & 0.0031 & 0.0035 & 0.0045 & 0.0055 & 0.0058 & 0.0040 & 0.0033 & 0.0016 \\
\hline$\%$ & 0.81 & 0.88 & 1.12 & 1.33 & 1.42 & 0.98 & 0.77 & 0.39 \\
\hline Average Tax Rate & 0.0685 & 0.0778 & 0.0852 & 0.0928 & 0.0972 & 0.1009 & 0.0984 & 0.1167 \\
\hline$k$ index of $\operatorname{tax} P_{K}$ & 0.0678 & 0.0692 & 0.0780 & 0.0843 & 0.0855 & 0.0675 & 0.0631 & 0.0419 \\
\hline $\begin{array}{l}\text { Contribution of total } \\
\text { expenditure } V^{K}\end{array}$ & 0.0050 & 0.0058 & 0.0073 & 0.0086 & 0.0092 & 0.0076 & 0.0069 & 0.0055 \\
\hline Vertical Equality $V^{\text {UL }}$ & 0.0067 & 0.0083 & 0.0093 & 0.0091 & 0.0104 & 0.0086 & 0.0070 & 0.0072 \\
\hline$\%$ & 213.60 & 235.60 & 205.72 & 165.00 & 177.64 & 215.67 & 214.84 & 440.80 \\
\hline Horizontal Equality $H^{u L}$ & 0.0017 & 0.0025 & 0.0020 & 0.0005 & 0.0012 & 0.0010 & 0.0001 & 0.0017 \\
\hline$\%$ & 54.30 & 69.72 & 44.53 & 8.67 & 20.19 & 25.64 & 3.44 & 102.14 \\
\hline Reordering Effect $R^{K}$ & 0.0019 & 0.0023 & 0.0028 & 0.0031 & 0.0034 & 0.0036 & 0.0036 & 0.0039 \\
\hline$\%$ & 59.30 & 65.88 & 61.20 & 56.32 & 57.45 & 90.03 & 111.41 & 238.66 \\
\hline $\begin{array}{l}\text { Transfer } \boldsymbol{B} \\
\text { Gini Coefficient before } \\
\text { Transfer }\end{array}$ & 0.3888 & 0.4021 & 0.4028 & 0.4136 & 0.4116 & 0.4072 & 0.4207 & 0.4207 \\
\hline $\begin{array}{l}\text { Gini Coefficient after } \\
\text { Transfer }\end{array}$ & 0.3080 & 0.3270 & 0.3248 & 0.3277 & 0.3277 & 0.3205 & 0.3187 & 0.3187 \\
\hline Redistribution Effect & 0.0808 & 0.0751 & 0.0780 & 0.0859 & 0.0839 & 0.0868 & 0.1021 & 0.1021 \\
\hline$\%$ & 20.78 & 18.68 & 19.35 & 20.77 & 20.38 & 21.31 & 24.26 & 24.26 \\
\hline Average Tax Rate & 0.2201 & 0.2075 & 0.2046 & 0.2267 & 0.2153 & 0.2169 & 0.2486 & 0.2486 \\
\hline$k$ index of transfer & 0.5021 & 0.4911 & 0.5179 & 0.4901 & 0.4964 & 0.5158 & 0.5078 & 0.5078 \\
\hline Contribution of transfer & 0.1417 & 0.1286 & 0.1332 & 0.1436 & 0.1362 & 0.1429 & 0.1680 & 0.1680 \\
\hline Vertical Equality & 0.0072 & 0.0200 & 0.0158 & 0.0202 & 0.0167 & 0.0095 & 0.0059 & 0.0059 \\
\hline$\%$ & 3.46 & 10.69 & 8.14 & 9.73 & 8.18 & 4.47 & 2.43 & 2.43 \\
\hline Horizontal Equity & -0.1345 & -0.1087 & -0.1175 & -0.1234 & -0.1196 & -0.1333 & -0.1621 & -0.1621 \\
\hline$\%$ & -166.54 & -144.67 & -150.67 & -143.68 & -142.52 & -153.68 & -158.80 & -158.80 \\
\hline Reordering Effect & 0.0609 & 0.0535 & 0.0553 & 0.0577 & 0.0523 & 0.0561 & 0.0659 & 0.0659 \\
\hline$\%$ & 75.44 & 71.26 & 70.89 & 67.20 & 62.39 & 64.65 & 64.58 & 64.58 \\
\hline
\end{tabular}

upward trend. This suggests that the degree of income inequality determined by the market is gradually widening.

Second, about $11.67 \%$ of the market income is used for tax in 2009, and transfer equivalent to $24.86 \%$ of market income. The government's net income and expenditure are significantly narrowing the income gap each year. By 2009, the government reduces $25.22 \%$ of the income gap. The Gini coefficient after net transfer is lower than the national overall level, indicating that the urban population income inequality is relatively weak.

Third, the decomposition of the redistribution effect of government net revenue and expenditure shows that vertical equity improvement plays the main role, accounting for more than $150 \%$. Most of the improvements in horizontal and vertical equity of the net income and expenditure are from the role of transfer, and the contribution is above $95 \%$. In 2004, the proportion reached $97.72 \%$.

Fourth, the progressivity of the total taxation increases and then decreases, which affects the tax income redistribution effect. The decomposition shows that vertical equity plays the main role, accounting for more than 150\% each year. Relatively speaking, the progressivity of transfer is increasing, mainly reflected in the promotion of horizontal equity. 


\section{Redistribution Effects of Different Government Incomes and Expenditures}

Expenditures from Residents to Government. In terms of residents' spending to government, income tax and four social security projects were selected (pension expenditure, medical insurance expenditure, unemployment insurance, provident fund). The results show that the redistribution effect of individual pension expenditure is negative, and the negative impact in 2006 is exacerbated, which may be due to the changes in the way and proportion of individual accounts payment implemented on January 1 of that year ${ }^{3}$. The contribution of personal medical insurance expenditure to income redistribution is negative, and there is an increasing trend every year. This shows that the setting of premium payment is widening the income gap to a certain extent, and is not conducive to improving the income distribution in the two most important elements of the social insurance system. The contribution of personal income tax and provident fund to redistribution is positive, and the role is expanding over time. The impact of unemployment insurance on income redistribution is relatively weak.

On the whole, the combined redistribution effect of personal income tax and social insurance expenses from residents to government is positive, and can play a role in regulating the income redistribution. From the changing trend, the role of household expenditure in improving income distribution is first expanded and then narrowed, with a turning point at the year 2006.

Transfers from Government to Residents. The role of pension in adjusting income distribution is relatively stronger in the transfers from government to residents. Although the main function of unemployment insurance, social relief and other projects is to adjust distribution and help low-income people, their role is very

${ }^{3}$ From January 1, 2006, the size of personal accounts was adjusted to $8 \%$ of wage from $11 \%$, all formed by personal payment, and unit payment is no longer included in the personal account. weak, which might be because few urban workers can satisfy the standards of social relief, and the usage of unemployment insurance is limited by many restrictions, such as unemployment registration and payment for at least one year.

The redistribution function of pension basically maintains a rising tendency. Social relief shows a clear jump in 2008, which is related to the obvious increase of the minimum living guarantee expenditure and frequent natural disasters. But the role of unemployment insurance continues to decline, the provident fund's adjustment in most years has been negative. This reflects that the functions of a series of fiscal policies have not been fully implemented yet, and there is still much room for adjustment.

\section{Conclusions}

The results of this paper reveal that the role of government net transfer in income distribution is gradually increasing facing the widening income gap among urban residents. In 2009, $25.22 \%$ of the income gap reduced, which is mainly reflected in vertical equity adjustment. Although both transfers and taxes play a positive role, their contributions present great disparities. Transfers take up more than $95 \%$ of the whole effects. In the expenditure of residents to government, the redistribution effects of pension and medical insurance expenses are negative. However, the redistribution effects of personal income tax and provident fund are obvious., Only the pension has a clear redistribution effect in the transfers of government to the residents. Based on the above conclusions, China's redistribution policies still have adjustment spaces in the following areas.

First, the redistribution function of tax system needs to be strengthened further. On the one hand, as one of the main tools of regulating income distribution, personal income tax's tax base should gradually shift from "income' to 'wealth". Only when the comprehensive income tax system is built can we touch the core of income distribution and strengthen the adjustment. Of course, this needs to be established on the basis of tax collection and 
management improvement. On the other hand, one should explore the income distribution function of value-added tax, corporate income tax, property tax and other major taxes, and implement social justice into tax reform standards.

Second, the primary feature of social insurance is mutual aid, and different policies can play a positive or negative redistribution effect in terms of premium raising and compensation. Progressive payment ratio based on income or wealth can be developed to improve social insurance fund raising system and create greater space for the improvement of social insurance redistribution function.

Finally, transfer methods such as social relief, unemployment insurance, have clear redistribution functions. The orientation to the 'bottom of social protecting net' should be strengthened to adjust the structure and improve the aspects.

\section{References}

1. Musgrave R. A., Thin T. Income tax progression, 1929-48. The Journal of Political Economy, 1948 , vol. 56, no. 6, pp. $498-514$.

2. Kakwani N. C. Measurement of Tax Progressivity: an International Comparison. The Economic Journal, 1977, vol. 87, no. 345, pp. 71-80.

3. Suits D. B. Measurement of tax progressivity. American Economic Review, 1977, vol. 67, no. 4, pp. 747-752.

4. Davies D. G. Measurement of Tax Progressivity: Comment. American Economic Review, 1980, vol. 70, no. 1, pp. 204-207.

5. Davidson R., Duclos J. Y. Statistical Inference for the Measurement of the Incidence of Taxes and Transfers. Econometrica, 1997, vol. 65, no. 6, pp. 1453-1465.

6. Atkinson A. B. Horizontal Equity and the Distribution of Tax Burden. In Aaron H., Boskin M. (eds.) The Economics of Taxation. Washington DC, Brookings Institution, 1980, pp. 3-18.

7. Plotnick R. A measure of horizontal inequity. The review of Economics and Statistics, 1981, vol. 63 , no. 2, pp. 283-288.

8. Kakwani N. C. On the Measurement of Tax Progressivity and Redistributive Effect of Taxes with Applications to Horizontal and Vertical Equity. Advances in Econometrics, 1984, vol. 3, pp. 149-168.

9. Aronson J. R., Johnson P., Lambert P. J. Redistributive Effect and Unequal Income Tax Treatment. The Economic Journal, 1994, vol. 104, no. 422, pp. 262-270.

10. Aronson J. R., Lambert P. J. Decomposing the Gini Coefficient to Reveal the Vertical, Horizontal and Reranking Effects of Income Taxation. National Tax Journal of Econometrics, 1994, vol. 47, no. 2, pp. 273-294.

11. Urban I., Lambert P. J. Redistribution, Horizontal Inequity, and Reranking: How to Measure Them Properly. Public Finance Review, 2008, vol. 36, no. 5, pp. 563-587.

12. Pechman J. A. The future of the income tax. American Economic Review, 1990, vol. 80, no. 1 , pp. 1-20.

13. Björklund A., Jäntti M. Intergenerational Income Mobility in Sweden Compared to the United States. American Economic Review, 1997, vol. 87, no. 5, pp. 1009-1018.

14. Wagstaff A., etc. Redistributive Effect, Progressivity and Differential Tax Treatment: Personal Income Taxes in Twelve OECD Countries. Journal of Public Economics, 1999, vol. 72, no. 1, pp. 73-98.

15. Zandvakili S. Income distribution and redistribution through taxation: An international comparison. Empirical Economics, 1994, vol. 19, no. 3, pp. 473-491.

16. Sahn D. E., Younger S. D., Simler K. R. Dominance testing of transfers in Romania. Review of Income and Wealth, 2000, vol. 46, no. 3, pp. 309-327.

17. Wagstaff A., van Doorslaer E., Watanabe N. On Decomposing the Causes of Health Sector Inequalities with an Application to Malnutrition Inequalities in Vietnam. Journal of Econometrics, 2003, vol. 112, no. 1, pp. 207-223.

18. Lambert P. J. On the Redistribution Effect of Taxes and Benefits. Scottish Journal of Political Economy, 1985, vol. 32, no. 1, pp. 39-54.

19. Duclos J. Y. Progressivity, Redistribution and Equity, with Application to the Britain Tax and Benefit System. Public Finance / Finances Publiques, 1993, vol. 48, no. 3, pp. 350-365.

20. Urban I. Redistributive effects of direct taxes and social benefits in Croatia. Doct. Diss. Slovenia, 2010. 199 p. 
AUTHOR Liи Baihui - PhD in Economics, Assistant Research Fellow of National Academy of Economic Strategy, Chinese Academy of Social Science, Beijing, China ( $9^{\text {th }}$ floor, Zhongye Building, 28 Shuguang Xili St., Chaoyang District, Beijing 100028, China); e-mail: liubaihui0515@163.com

ИНФОРМАЦИЯ ОБ АВТОРЕ Лиу Байхиу - кандидат экономических наук, младший научный сотрудник Национальной академии экономической стратегии, Китайская академия социальных наук, г. Пекин, Китай (100028, Китай, г. Пекин, Район Чаоянг, ул. Шугуан Хили, 28, строение Зонгуе, этаж 9); e-mail: liubaihui0515@163.com

FOR CITATION Liu Baihui. Redistributive Effect of Taxes and Transfers: Evidence from China. Journal of Tax Reform, 2017, vol. 3, no. 1, pp. 43-51. DOI: 10.15826/ jetr.2017.3.1.030

ДЛЯ ЦИТИРОВАНИЯ Лиу Байхиу. Перераспределительные эффекты налогов и трансфертов: опыт Китая / Лиу Байхиу // Journal of Tax Reform. - 2017. T. 3, № 1. - C. 43-51. - DOI: 10.15826/itr.2017.3.1.030

ARTICLE INFO Received February 14, 2017; accepted March 27, 2017

ИНФОРМАЦИЯ О СТАТЬЕ Дата поступления 14 февраля 2017 г.; дата принятия к печати 27 марта 2017 г. 